\title{
THE GENUS SIGANUS IN THE COLLECTION OF THE NATIONAL INSTITUTE OF OCEANOLOGY (SIGANIDAE)
}

\author{
by \\ BURHANUDDIN, SULARTO MARTOSEWOJO, MALIKUSWORO HUTOMO \\ and ASIKIN DJAMALI
}

(Manuscript received June 11, 1974)

\begin{abstract}
Ten species of the genus Siganus namely Siganus vulpinus, S. corallinus, S. spinus, S. oramin, S. javus, S. virgatus, S. puellus, S. chrysospilos, S. vermiculatus, and S. guttatus are available in the collection of the Lembaga Oseanologi Nasional (LON = National Institute of Oceanology). The description of each of these species is presented.
\end{abstract}

\section{IKHTISAR}

Hanya sepuluh jenis ikan dari marga Siganus yakni Siganus vulpinus, S. corallinus, S. spinus, S. oramin, S. javus, S. virgatus, S. puellus, S. chrysospilos, S. vermiculatus dan $S$. guttatus terdapat dalam koleksi Lembaga Oseanologi Nasional. Tulisan ini mencandrakan kesepuluh jenis tersebut.

\section{INTRODUCTION}

Siganids are among the many culturable fishes in the Indo Pacific region. This group of fishes recently attracts many mariculturists because of their relatively high protein contents (Siganus javus) and good taste and widely distributed in the coastal waters of the Indo-Pacific, Red Sea, and the Mediterranean regions (SigANID MARICULTURE GrouP 1972, LAM 4974).

Among the biological problems faced in the study of the siganid culture is the lack of information on the distribution of the species and the considerable confusion in literature regarding the taxonomic aspects of this fish group (LAM 1974). 
This paper, therefore, is intended to provide more information on the species occurring in the Indonesian waters and to help clarifying part of the confusion.

\section{MATERIALS AND METHODS}

The material studied were monthly collected from various parts of Indonesian waters by using trap and net, but a small number of specimens were purchased from fish market. Most specimens were preserved in $4 \%$ formaldehyde, but a small number in $70 \%$ alcohol.

Measurements were done by using a set of Mitutoyo callipers, reading directly to the nearest hundredth of millimeters.

The standard length is a measurement from the tip of the snout to the end of the hypural. The latter point is determined by bending the caudal fin from side to side and noting the position of the abrupt wrinkle formed at the base of the ray; head length is measured from the tip of the snout to the extreme posterior margin of the opercular flap; pectoral length from the base of pectoral to the tip of the longest ray; fin spine from the proximalmost point of the posterior axil formed by the element with the dorsal body contour to the distal tip of the element, snout length from the tip of the snout to the extreme anterior margin of the orbit; eye diameter is the horizontal distance between the opposite margins; interorbital space refers to the distance between the middle part of the upper margins of the orbits; fins followed by number indicated the number of spines (Roman numerals) and rays (Arabic numerals) in them.

Compared to the descriptions of DE BEAXFORT and CHAPMAN (1951), HerRe (1953) and MunRo (1967), more variations are observed in the material studied.

\section{Siganus vulpinus (SCHLEGEL \& MULLER 1844)}

\section{(Plate I, 1)}

Teuthis vulpina GUNTHER 1873: 91.

Lo vulpinus Jordan \& Seale 1906: 361. - Herre \& Montalban 1928: 182, pl. 6.

Lo unimaculatus Evermann \& SeAle 1907: 98-99, fig. 19.

Amphacanthus vulpinus WEBER, 1913: 30.

Material. - 1 specimen, 117.00 mm; Panjang Island; NCIP. 1660. 
Description. - D. XIII, 10 A. VII, 9 P. ii, 14 V. I, 3, I

Height: 2.27. Head: 3.16. Eye: 4.02, 2.14 in elongate, tubiform and compressed snout. Pectoral: 4.39 in standard length. Anterior nostril with low brim, cheeks scaly. First dorsal spine somewhat longer than eye; fourth longest, as long as snout or twice of eye. Last dorsal spine less than twice of eye. Third anal spine longest, equal to or slightly longer than snout, 1.28 in interorbital space. Mouth small with long pointed teeth and two lateral cusps on every tooth. Colour of preserved specimen brownish; a broad dark brown band from origin of dorsal, through eye, to tip of snout; rest of head whitish with numerous brown dots; thorax dark brown; anterior ventral brownish.

\section{Siganus corallinus (CUVIER \& VALENCIENNES 1835)}

$$
\text { (Plate I, 2) }
$$

Teuthis corallina Gunther 1873: 88. - Herre \& Montalban 1928: 59, pl. 1, fig. 2. Siganus corallinus JORDAN \& RICHARDSON 1908: 271.

Material. — 2 specimens, 92.22 -107.46 mm; Panjang Island; NCIP. 1663, 2808. - 1 specimen, 148.70 mm; Ambon; NCIP. 3446.

Description. - D. XIII, 10 A. VII, 9 P. ii, 14 -15 V. I, 3, I

Height: 1.96-2.12. Head: 3.22-3.60. Eye: 3.31-3.66, 1.51-2.05 in snout. Snout: 1.79-2.22 in head. Pectoral: 3.93-4.76 in standard length. Body oblong, rather deep, compressed. Interorbital space somewhat convex. Upper and lower profiles of head before eyes concave. First dorsal spine more or less equal to eye; sixth or seventh spine longest, slightly longer than snout and almost twice of the eye. Last spine as long as eye or somewhat shorter. Soft dorsal pointed; median rays longest, slightly longer than snout. Soft anal equal to soft dorsal. Pectoral equal to snout and eye. Caudal deeply forked, lobes pointed. Colour of preserved specimen: brownish, becoming paler on the middle of body; dark brown spots dispersed on entire body and head, those on the opercle and caudal peduncle larger in size; fins, brownish basally, whitish distally. Colour of fresh specimen: Head yellow with a dark brown band from lower jaw across eye to base of dorsal; body and fins yellow; small brilliant blue sports sprinkle on head and body; narrow, broken bluish lines on lower part of body, beginning from lower base of pectoral to fifth anal spine. 
Siganus spinus (LINNAEUS 1758)

$$
\text { (Plate II, 1) }
$$

Teuthis striolata GunTHER 1873: 89, pl. LIX, fig. A. — HERRE \& MONTALBAn 1928:

177, pl. 5, fig. 2.

Teuthis marmorata DAY 1875: 166, pl. XL, fig. 2.

Teuthis siganus SAUVAGE 1891: 287. Amphacanthus

marmoratus WEBER 1913: 329.

Material. - 1 specimen, 93.00 mm; Kongsi Island; NCIP. 3448. - 1 specimen, $139.00 \mathrm{~mm}$; Panggang Island; NCIP. 3445. - 1 specimen, 168.00 mm; Jukung Island; NCIP. 1388. - 1 specimen, 162.00 mm; Komodo Island: NCIP. 1662.

Description. - D. XIII, 10 A. VII, 9 P. ii, 14 V. I, 3, I

Height: 2.51-2.73. Head: 3.71-4.09. Eye: 2.78-3.40, 1.20-1.40 in snout. Interorbital space flat, 1.20 in eye. Cheeks with few deciduous scales, embedded in skin. Anterior nostril with long flap. First dorsal spine slightly shorter than eye, seventh spine longest, 1.19-1.45 in snout, last one shorter than eye. Soft dorsal rounded, median rays longest, longer than either snout or eye. First anal spine longer than first dorsal. Pectoral: 0.71 - 0.82 in head, 4.48 - 5.02 in standard length. Caudal slightly emarginate, almost truncate when extended. Colour of preserved specimen: brownish on upper part, lighter on lower part; interorbital space crossed by two thin light lines; distinct white lines, narrower than the interspace, forming a network; caudal peduncle with two thin vertical white lines (one of them disappears in preserved specimen); fins mottled with brown and white dots. Four light and dark lines in fresh, faded after preservation.

\section{Siganus canaliculatus (PARK 1797)}

$$
\text { (Plate II, 2) }
$$

Teuthis albopunctata GUNTHER 1873: 88.

Teuthis margaritifera DAY 1875: 167, pl. XL, fig. 5.

Amphacanthus oramin WEBER 1913: 329.

Teuthis oramin HerRE \& MONTALBAN 1928: 165, pl. 5, fig. 1.

Material. - 1 specimen, 167.00 mm; Kongsi Island; NCIP. 3451. - 3 specimens, 89.36-162.00 mm; Pari Island; NCIP. 1629, 1714, 2038. - 2 specimens, 189.00-196.00 mm; Gosong Island; NCIP. 1510, 1511. — 1 
specimen, 140.44 mm; Lipan Island; NCIP. 1642. - 2 specimens, 164.00 -189.00 mm; Jukung Island; NCIP. 1690, 1387. — 1 specimen, 180.00 mm; Ceper Island; NCIP. 2749. - 1 specimen, 159.00 mm; Genteng Island; NCIP. 1687. - 2 specimens, 63.66-75.90 mm; Petundang Island; NCIP. 949, 1698. - 6 specimens, 116.28-150.58 mm; Yamdena Island; NCIP. OB. 46.534.4, 28, 51, 77, 80. — 3 specimens, 124.70 -128.00 mm; Kalidupa Island; NCIP. OB. 46.534.18, 19.20. - 3 specimens, 180.00-224.00 mm; Komodo Island; NCIP. OB. 46.534.15, 16, 17. - 3 specimens, 121.22-173.00 mm; Larat Island; NCIP. OB. 46.534.56, 57, 58. - 1 specimen, $119.00 \mathrm{~mm}$; Sailu Island; NCIP. OB. 46.534.60. - 1 specimen, $108.44 \mathrm{~mm}$; Jinatu Island; NCIP. OB. 46.534.48.49 - 1 specimen, $111.26 \mathrm{~mm}$; Ambon; NCIP. OB. 46.534.50. - 1 specimen, $119.00 \mathrm{~mm}$; Macan Island; NCIP. 1684. — 2 specimens, 84.24 - 91.42 mm; Benoa; NCIP. 1688, 1689.

Description. - D. XIII, 10 A. VII, 9 P. ii, 14 V. I, 3, I.

Height: 2.20-2.66. Head: 3.00-3.95. Eye: 1.16-1.60 in snout, 3.03 - 3.64 in head. Snout: 2.20 - 2.60. Pectoral: 4.30 - 6.31 in standard length. Anterior nostril with low brim. Cheeks naked. First dorsal spine slightly longer than eye; fifth or sixth is longest, 1.10-1.25 in snout, more or less twice of eye. First dorsal spine longer than last one. Soft dorsal rounded, median rays only very slightly longer than anterior ones. First anal spine slightly longer than first dorsal spine; third and fourth subequal. Soft anal rounded. Caudal forked. Colour of preserved specimens: brownish on upper part, silvery on lower part; head, body and tail covered with numerous rounded white spots; a dark blotch present immediately behind and below base of lateral line.

Siganus javus (LINNAEUS, 1766)

(Plate III, 1)

Teuthis Java DAY 1875: 165, pl. XXXIX, fig. 5.

Siganus javus JORDAN \& SEALE 1907: 35.

Teuthis javus HerRe \& MONTAIBAn 1928: 175, pl. 5. fig. 3.

Material. — 2 specimens, 243.00 - 269.00 mm; Kongsi Island; NCIP. 3449, 3450. - 1 specimen, $67.62 \mathrm{~mm}$; Indramayu; NCIP. 3442. - 2 specimens, 111.50-164.00 mm; River mouth of Sungai Kapuas; NCIP. 1708, 1709. 
Description. - D. XIII, 10 A. VII, 9 -10 P. ii, 15 -16 V. I, 3, I.

Height: 2.00-2.90. Head: 3.40-3.96. Eye: 3.20-3.89, 1.30-1.66 in snout. Snout: 2.40 - 2.52 in head. Pectoral: 4.59 - 5.86 in standard length. First dorsal spine slightly shorter than, or as long as eye; sixth or seventh spine longest, longer than snout, nearly twice of eye; last dorsal spine nearly equal to snout. Soft dorsal angular, post median rays longest. First anal spine slightly longer than eye.; third spine longest, equal to or slightly longer than snout or half as long as eye; posterior spines subequal, slightly less than third one. Soft anal more rounded than soft dorsal. Pectoral equal to head without snout or slightly longer. Caudal emarginate. Colour of preserved specimens: brownish on upper part, lighter or silvery on side of head, horax, belly and lower part of body and tail; back and nape with white spots, these tend to fuse into elongate broken lines and fuse into longitudinal wavy lines on lower part of body.

Siganus virgatus (CUVIER \& VALENCIENNES 1835) (Plate III, 2)

Teuthis virgata Day 1875: 166, pl. XL, fig. 3. - Herre \& Montaiban 1928: 171, pl. 4, fig. 3. Siganus virgatus Evermann \& SEALE 1907: 98. — JONDAN \& RiCHARDSON 1908: 271. -

De Beaufort \& Chapman 1951: 113-114. - Munro 1955: 210.

Material. - 2 specimens, 129.50 -147.00 mm; Jakarta Bay; NCIP. 1703, 1706. — 1 specimen, 131.40 mm; Untung Jawa Island; NCIP. 1704. - 3 specimens, 138.34-175.00 mm; Pancalirang Island; NCIP. 1693, 1694, 1695. - 1 specimen, 149.60 mm; Karang Beras Island; NCIP. 3447. - 1 specimen, $181.00 \mathrm{~mm}$; Lipan Island; NCIP. 1692. — 1 specimen, $111.00 \mathrm{~mm}$; Pontianak; NCIP, 1705. - 2 specimens, 45.80 - 46.40 mm; Benoa (Bali); NCIP. 1701. - 3 specimens, 82.80 - 90.00 mm; Sasiil Island; NCIP. OB. 46.534.81, 82, 83. - 1 specimen, 129.30 mm; Ujung Pandang; NCIP. 1707.

Description. - D. XIII, 10 A. VII, 8 - 9 P. ii. 14 -15 V. I, 3, I.

Height: 1.80-2.23. Head: 3.03-3.72. Eye: 2.77-3.56, 1.19-1.68 in snout. Snout: 1.99-2.50. Pectoral: 3.75-4.40. Anterior nostril with low brim, higher posteriorly, suggesting a small flap. Check scales deciduous. First dorsal spine more or less equal to eye. Last spine 
more or less equal to snout. Soft dorsal angular and high, median rays longer than the longest spine. First anal spine longer than eye but shorter than head. Caudal emarginate or slightly forked. Colour of preserved specimens: brown, brownish or light brown; three to four dark stripes on snout, three to four stripes on interorbital space and three others behind eye, continued on nape by irregular short stripes and dark round spots in adult specimens; a dark brown band bordered by dark brown lines running from chin through eye to base of dorsal; a similar band tapering inferiorly from between third and fifth dorsal spines to above base of pectoral.

Siganus puellus (SCHLEGEL 1852)

(Plate IV, 1)

Teuthis puella Gunther 1873: 91. - Herre \& Montalban 1928: 169, pl. 4, fig. 3. Siganus puellus Fowler 1928: 284-285. — De BEAUfORT \& CHAPMAn 1951: 116-117.

Material. - 3 specimens, 140.00 -194.00 mm; Kongsi Island; NCIP 3452, 3453, 3454.

Description. - D. XIII, 10 A. VII, 9 P. ii, 14 V. I, 3, I.

Height: 2.24-2.43. Head: 3.39-3.57. Eye: 3.61-4.01, 1.78-1.94 in snout. Snout: 2.03 -2.06. Interorbital space: 2.87 in head, 1.48 in eye, 0.76 in snout. Pectoral: 4.71 - 5.02. First dorsal spine more or less equal to eye, following spines increasing in length to the sixth or seventh, which is nearly twice of the eye, but not longer than snout. Soft dorsal distinctly pointed, median rays longest, which are more or less equal to snout and eye. First anal spine: 1.20-1.40 in first dorsal, following spines increasing in length to the last, which is less than snout and half the eye. Soft anal similar to soft dorsal but shorter. Caudal forked. Colour of preserved specimens: brownish. A dark brown oblique band from lower jaw to eye. Black spots spread on the nape. Fins brownish basally, whitish distally. Colour of fresh specimens: yellow. An oblique dark brown band beginning from the origin of dorsal through eye to lower jaw, on the upper portion of the eye, there are some darker or black spots. Body with blue vertical undulating lines on anterior portion and alike horizontal lines of similar colour posteriorly. Fins, yellow. 
Siganus chrysospilos (BLEEKER 1852)

(Plate IV, 2)

Teuthis hexagonata Gunther 1873: 89. - Herre \& Montalban 1928: 162, pi. 2, fig. 1. Teuthis sutor DAY 1875: 167.

Siganus punctatus JoRdAN \& SEALE 1906: 360.

Material. — 2 specimens, 115.46-127.46 mm; Air Island; NCIP. 3443, 3444. - 1 specimen, $220.00 \mathrm{~mm}$; Jukung Island; NCIP. 1389. - 1 specimen, $252.00 \mathrm{~mm}$; Petundang Island; NCIP. OB. 46.534.1. 3 specimens, 55.70-66.84 mm; Benoa (Bali); NCIP. 1696, 1700. — 3 specimens, 111.76-122.30 mm; Kai Island; NCIP. B. 46.534.65, 66, 67.

Description. - D. XIII, 10 A. VII, 9 P. ii, 14 -15 V. I, 3, I.

Height: 1.91-2.15. Head: 3.17-3.77. Eye: 2.96-4.03, 1.26-1.98 in snout. Interorbital space convex. Profile of upper head sloping in an almost straight line, with a slight convexity at interorbital space and a slight concavity on snout. Anterior nostril with low brim; posterior nostril larger than anterior one, somewhat triangular. In young specimens anterior nostril with a posterior flap, which gradually disappears with age. Cheek scaly. First dorsal spine more or less equal to eye: fifth to seventh spines longest, slightly longer than snout; last dorsal spine slightly shorter than snout, but much longer than first one. Soft dorsal angular; longest ray slightly longer than snout. First anal spine slightly longer than first dorsal spine; third to last anal spines longest, slightly longer than snout. Soft anal similar to soft dorsal; longest ray slightly shorter than longest dorsal ray. Caudal deeply forked; upper lobe somewhat longer. Colour of preserved specimens: light brown. Head, body and tail covered with lighter or darker spots of various sizes but not larger than pupil. The interspaces between spots forming a network much narrower than spots. In some specimens spots darker than interspaces. A round dark or black blotch as large as or slightly larger than eye, as base of lateral line present in young specimens, but absent in adult ones.

Siganus vermiculatus (CUVIER \& VALENCIENNES 1835)

$$
\text { (Plate } \mathrm{V}, 1)
$$

Teuthis vermiculata Day 1875: 166, pi. XL, fig. 1. - Herre \& Montalban 1928: 179, pl. 3, fig. 1 . 
Siganus vermiculatus SEALE 1910: 283. — De BEAUfORT \& CHAPMAN 1951: 121 -123. — MUNRO 1955: 210.

Material. — 1 specimen, 155.00 mm; Air Kecil Island; NCIP. 1710. — 2 specimens, 100.00-126.00 mm; Untung Jawa Island; NCIP. 2810, 2811. - 1 specimen, $271.00 \mathrm{~mm}$; Karang Island; NCIP. 1711. - 1 specimen, 177.00 mm; Seribu Island; NCIP. 1712. — 2 specimens, 215.00-216.00 mm; Ambon; NCIP. OB. 46.534.8, 9.

Description. - D. XIII, 10 -11 A. VII, 9 P. ii, 14 - 15 V. I, 3, I.

Height: 1.80-2.05. Head: 3.20-3.79. Eye: 3.09-3.78, 1.31-1.92 in snout. Snout: 1.90-2.35. Pectoral: 4.06-5.18 in standard length. First dorsal spine shorter than eye; subsequent spines to sixth or seventh spine increasing in length, longer than snout but shorter than snout and half of eye, the spine behind the seventh slightly shorter but the last as long as or longer than sixth or seventh. Soft dorsal more or less pointed; median rays longest, more or less equal to snout and eye. First anal spine slightly longer than eye; subsequent spines increasing in length, last spine equal to snout and half of eye. Soft anal similar to soft dorsal. Pectoral more or less equal to snout and eye. Caudal emarginate. Colour of preserved specimens: light brown or brown; thorax silvery. Body, tail and side of head covered by brown sinuous bands, nearly as board as interspace, irregularly curved, sometimes forming whirls, and arranged into more or less transverse bands on caudal pedunvle. Caudal spotted, forming five or six transverse rows. Soft dorsal and anal brown.

Siganus guttatus (BLOCH 1787)

(Plate V, 2)

Teuthis concatenata DAY 1875: 167, pl. XL, fig. 4.

Siganus lineatus JORDAN \& SEALE 1907: 35.

Amphacanthus conzatenatus WEBER 1913: 330.

Material. — 1 specimen, 98.28 mm; Untung Jawa Island: NCIP. 2809. 1 specimen, $171.00 \mathrm{~mm}$; Gosong Island; NCIP. 1631. - 3 specimens, 168.00-242.00 mm; Pancalirang Island; NCIP. 1632, 1633, 1630. - 3 specimens, 188.00-220.00 mm; Kangean Island; NCIP. OB. 131, 131a, 170. - 1 specimen, 199.00 mm; Saubi Island; NCIP. 82. 
Description. - D. XIII - XIV, 10 A. VI - VII, 9 -10 P. ii, 14 V. I, 3, I.

Height: 1.87 - 2.10. Head: 3.30 - 3.56. Eye: 3.10 - 3.64, 1.50 -1.93 in snout. Profile of head concave at nape, convex from eye to upper lip. Cheek scaly. Snout: 1.80-2.13 in head. Pectoral: 4.00-4.85 in standard length. First dorsal spine about three fourth or more of eye. Sixth or seventh dorsal spine longest, more or less equal to snout. Last spine about twice or as long as the first one. Soft dorsal angular; second or third ray longest, more or less equal to snout and half as long as eye. First anal spine slightly longer than eye; last spine longest, equal to snout or snout and half of eye. Soft anal similar to soft dorsal. Pectoral equal to snout and eye or slightly shorter. Caudal emarginate. Colour of preserved specimens: brown or dark brown; side of head and body silvery; body and tail with numerous light brown blotches, larger than network-forming interspaces, with a brown blotch behind base of dorsal; several lines may be present on side of head.

\section{ACKNOWLEDGEMENTS}

The authors are indebted to Dr. APRILANi SoEgIARTO, Director of the National Institute of Oceanology, for his encouragement; to Messrs. Sujatno Birowo, KasiJan Romimohtarto, and Kasim MoOsa for their valuable advices in preparing this manuscript.

We would like to thank Messrs. Sujoto and SuTOPo for their help in preparing the materials.

\section{REFERENCES}

BARNARD, K. H. 1925 -1927. A monograph of the marine fishes of South Africa. Ann. S. Afr. Mus. 21:1-1065.

DAY, F. 1878. The fishes of India I. Bernard Guaritch. London: 1-816.

De Beaufort, L. F. \& W. M. Chapman. 1951. The fishes of Indo-Australian Archipelago 9. E.J. Brill, Leiden: 1 - 484.

Evermann, B. W. \& A. SeaeE. 1907. Fishes of the Philippine Islands. Bull. U.S. Bur. Fish. 26: 1-476.

Fowler, H. W. 1928. The fishes of Oceania. Mem. Bernice P. Bishop Mus. 10: 3 $-540$. 
Gunther, A. C. L. C. 1873-1875. Fische der Sudsee. J. Mus. Godeffroy, 1: 1-515.

Herre, A. W. 1953. Check list of Philippine fishes. United State Government Printing Office Res. Rep. 20: 1-977.

Herre, A. W. \& H. R. Montalban. 1928. The Philippine siganids. Philippine J. Sci. 35(2) : $151-185$.

JoRDAN, D. S. \& A. SEALE. 1907. Fishes of the Islands of Lugon and Panay. Bull. U.S. Bur. Fish. 26: 1-376.

Yordan, D. S. \& R. E. Richardson. 1907. Fishes from islands of the Philippine Archipelago. Bull. U.S. Bur. Fish. 27: 1- 295.

LAM, T. J. 1974. Siganids their biology and mariculture potential. Aquaculture 3: 325 $-354$.

MunRo, I. S. R. 1955. The marine and fresh water fishes of Ceylon. Department of External Affairs, Canberra: 1-351.

-------- 1967. The fishes of New Guinea. Department of Agriculture, Stock and Fisheries, Port Moresby, New Guinea: 1-651.

SAuvage, M. H. 1891. Histoire naturelle des poissons de Madagascar. 16. Libraire Hachette Et C. Paris: 1-534.

SchultZ, L. P. 1943. Fishes of the Phoenix and Samoan Islands collected in 1930 during the expedition of the U.S.S. "Bushnell". Smith. Inst. U.S. Nat Mus. Bull. 180: 1 -316.

SCHULTZ, L. P. et al. 1953. Fishes of the Marshall and Marianas Islands 1. Smith. Inst. U.S. Nat. Mus. Bull. 202: 1 - 685.

SEALE, A. 1910. Fishes of Borneo, with descriptions of four new species. Philippine J. Sci. 1: 1-30.

Siganid Mariculture Group. 1972. Plans for a Siganid fish farming program. University of Hawaii: 1-23.

Smith, J. L. B. 1950. The sea fishes of Southern Africa. Central News Agency Ltd. South Africa: $1-550$.

Weber, M. 1913. Die Fische der Siboga Expedition. E.J. BRILL, Leiden: 1-710. 


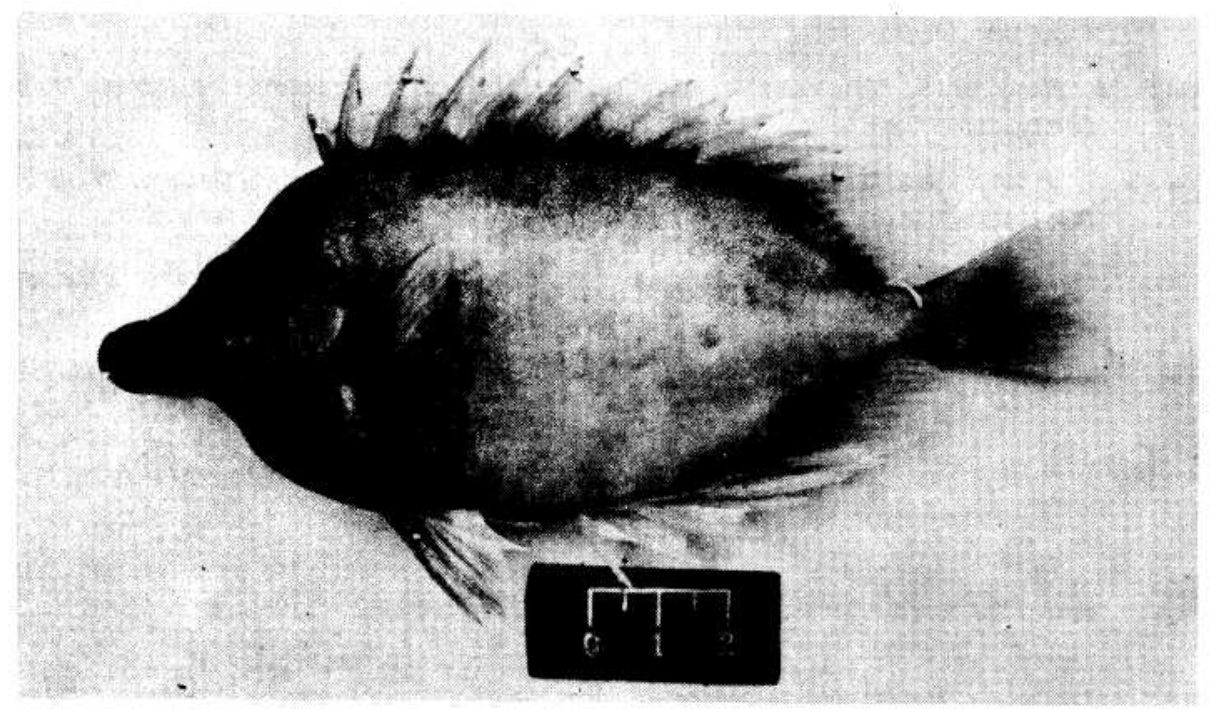

Figure 1. Siganus vulpinus (SCHLEGEL \& Muller 1844).

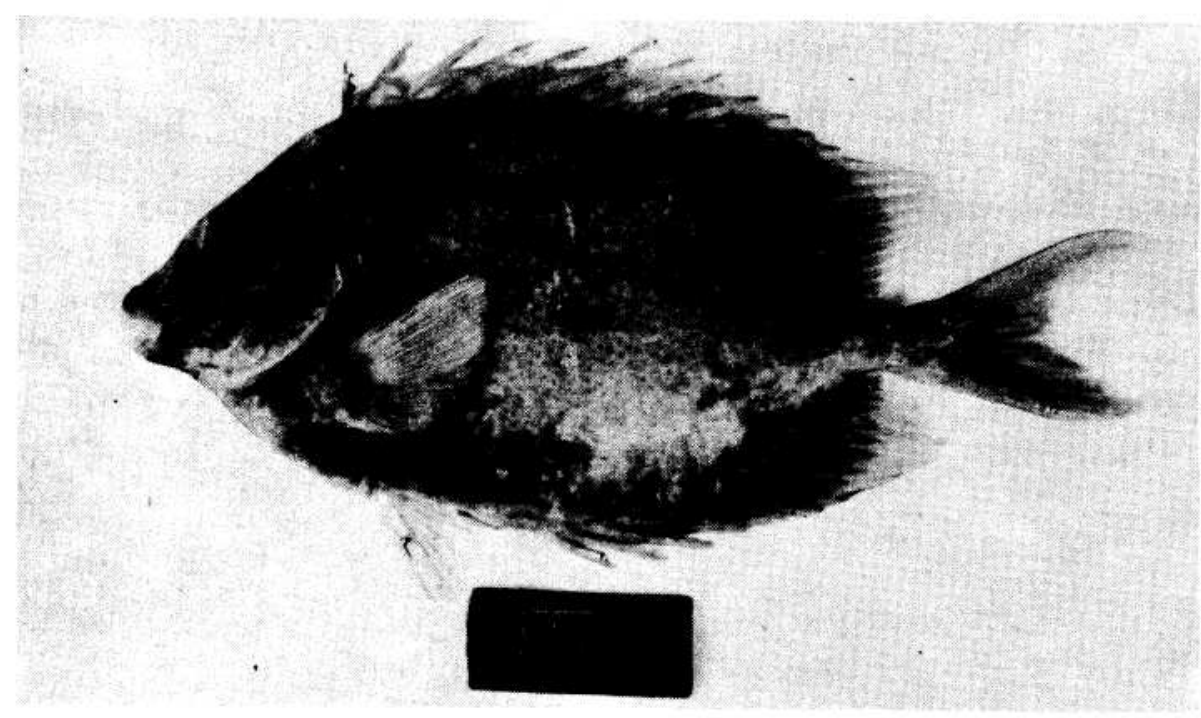

Figure 2. Siganus corallinus(CUVIER \& VALENCIENNES 1835). 


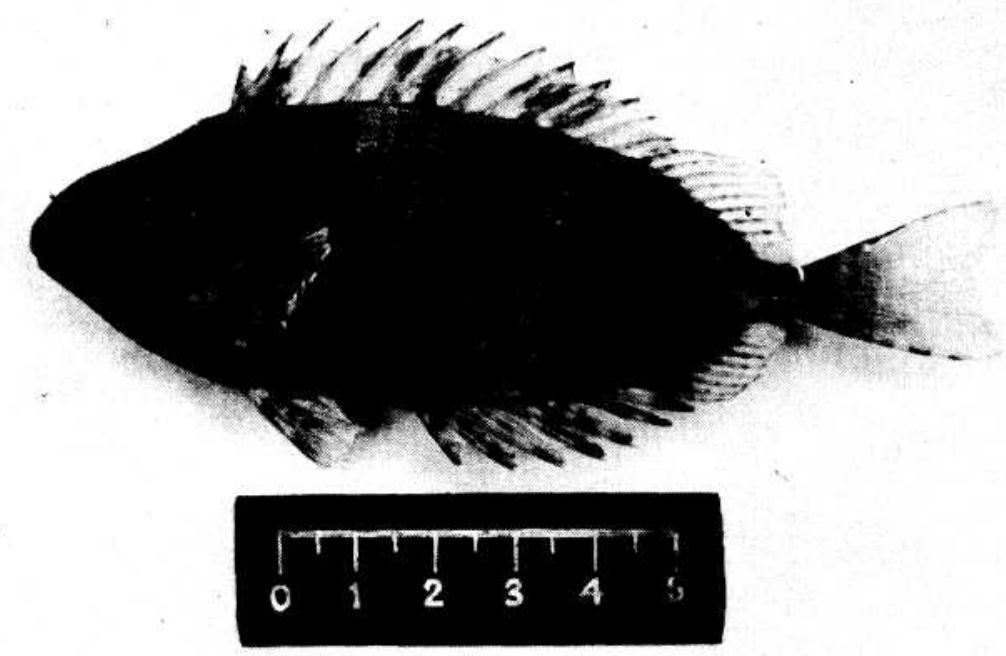

Figure 1. Siganus spinus (LinNAEUs 1758).

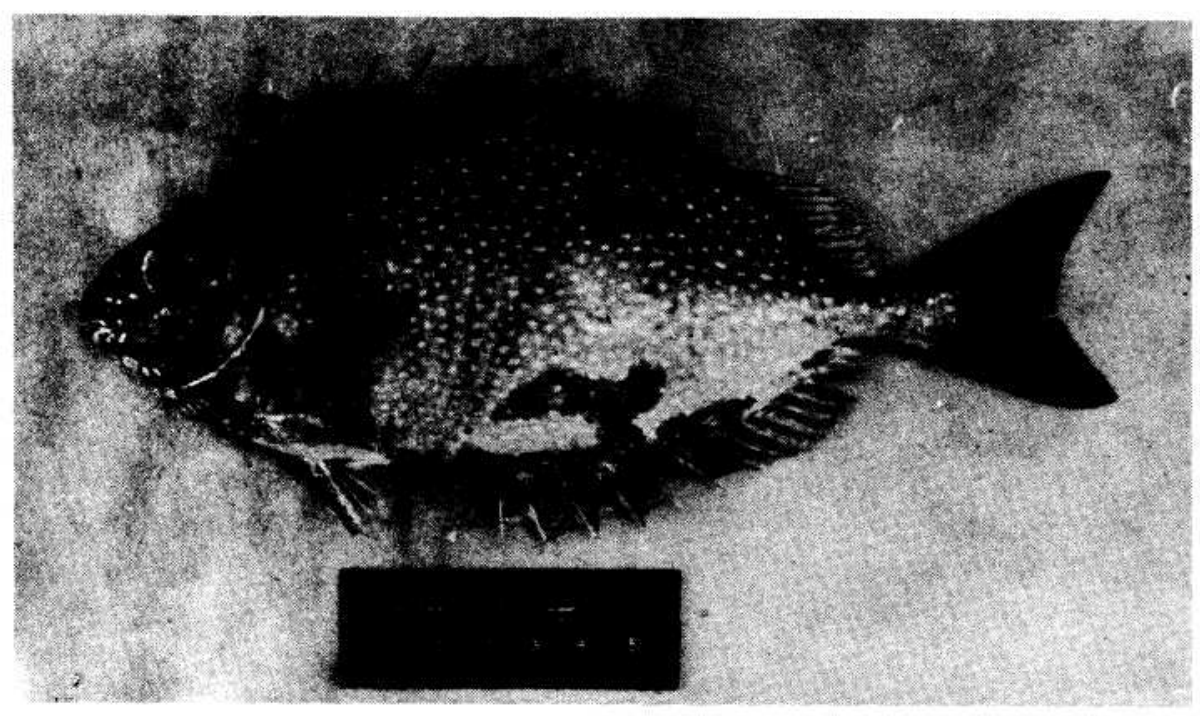

Figure 2. Siganus canaliculatus (PARK 1797). 


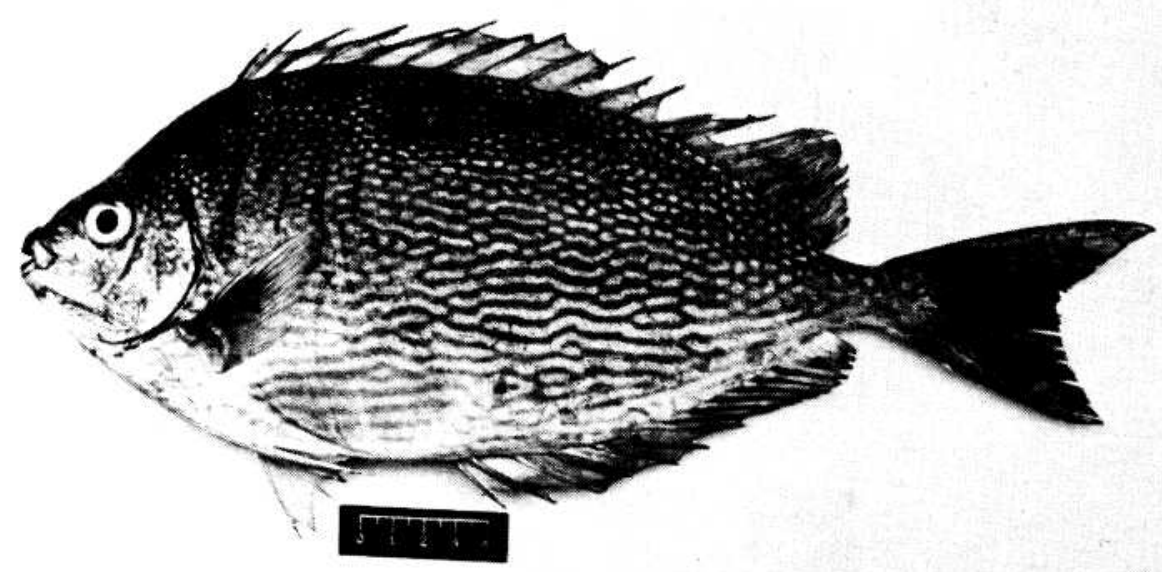

Figure 1. Siganus jarus (LinNaEus 1766).

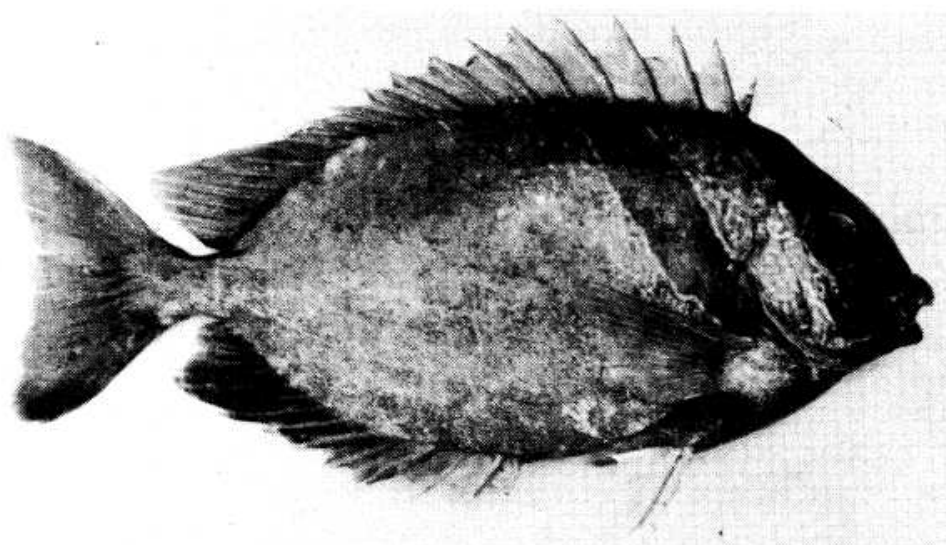

ГТग?

Figure 2. Siganus virgatus (Cuvier \& VAlenCiENNES 1801). 


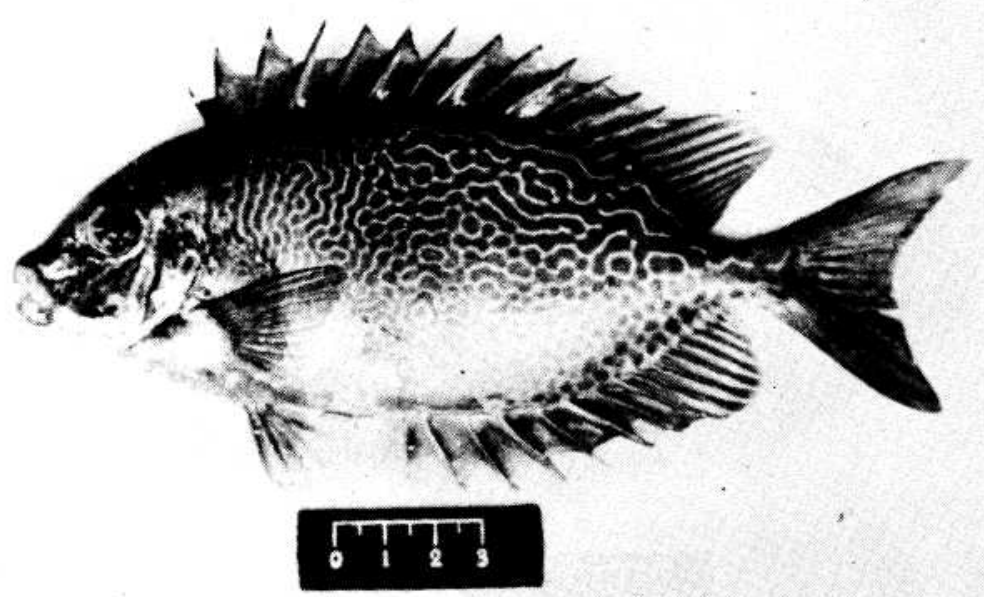

Figure 1. Siganus puellus (SCHLEGEL 1852).
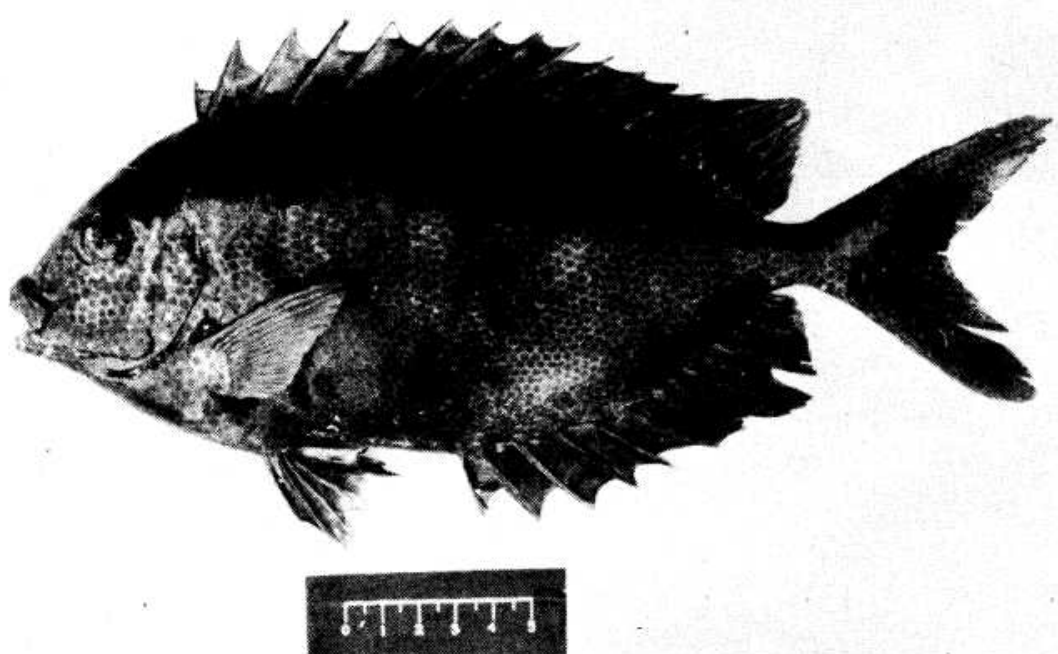

Figure 2. Siganus chrysospilos (BLEEKER 1852). 


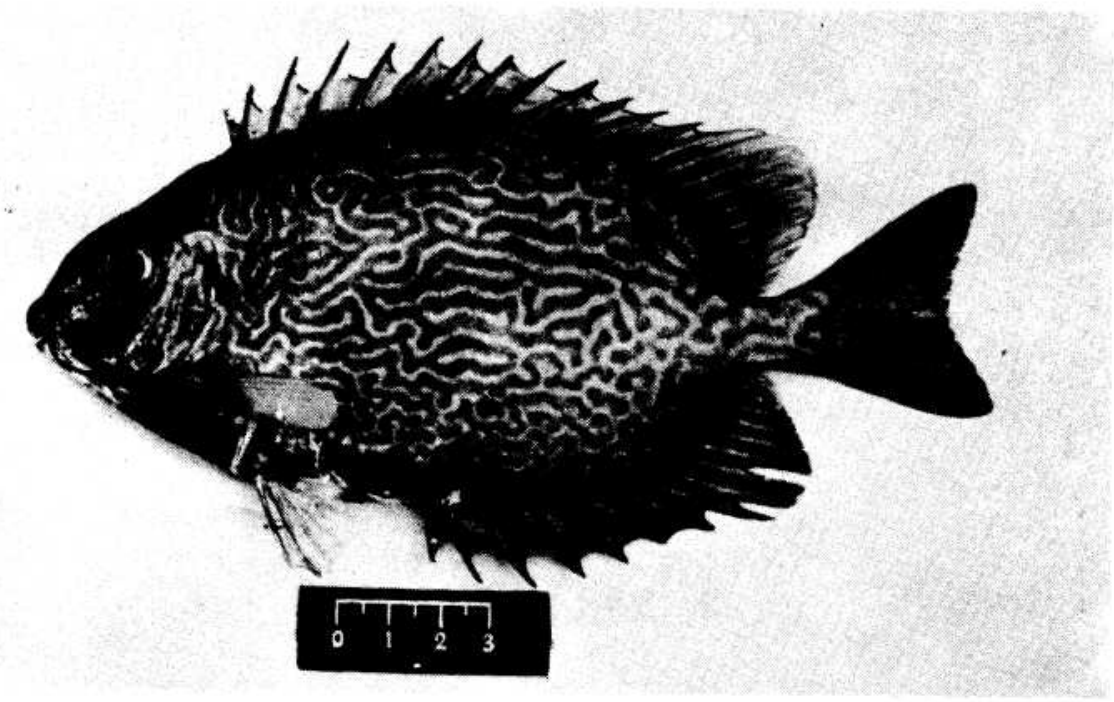

Figure 1. Siganus vermiculatus (CUVIER \& VALENCIENNES 1835).

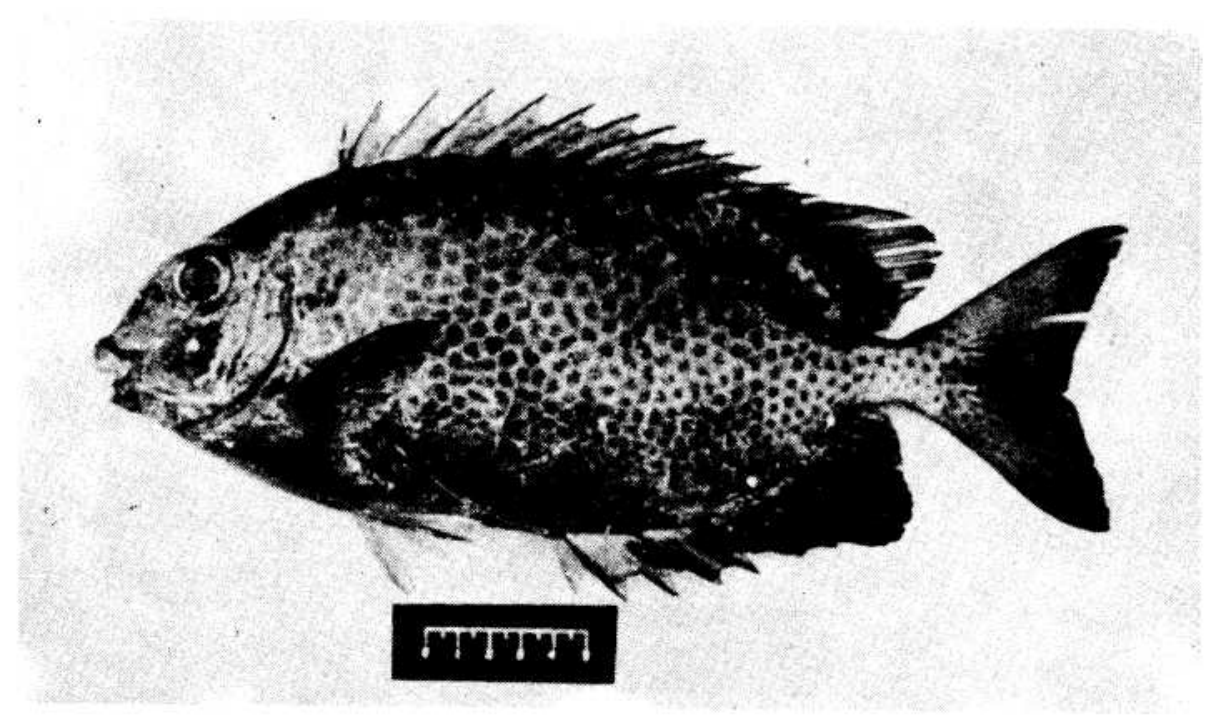

Figure 2. Siganus guttatus (BLOCH 1787). 